\title{
Effect of Uterine Flushing on Subclinical Endometritis in Repeat Breeding Cows
}

\author{
S. Alagar*, R. Ezakial Napolean, M. Selvaraju, G.A. Balasubramaniam and P. Selvaraj \\ Department of Veterinary Gynaecology and Obstetrics, Veterinary College and \\ Research institute, Namakkal - 2, India \\ *Corresponding author
}

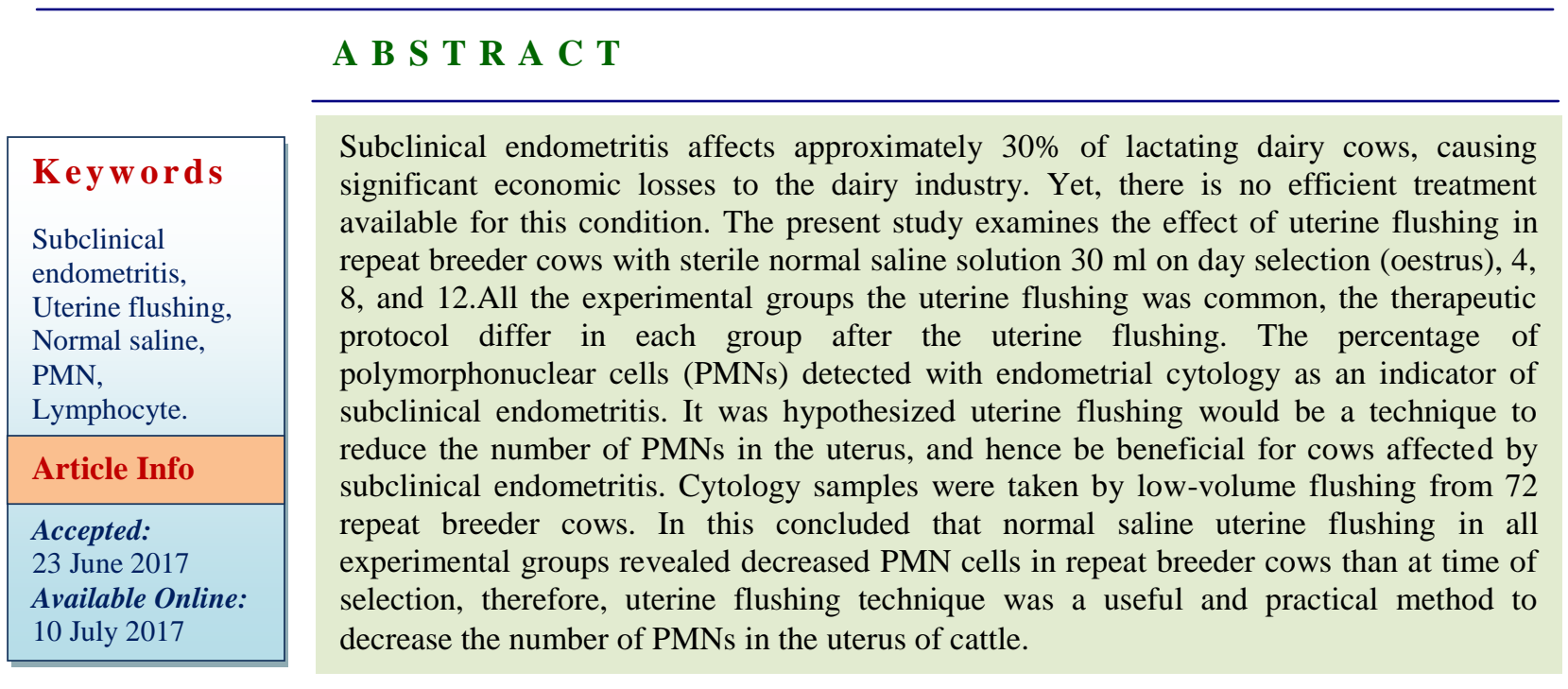

\section{Introduction}

Subclinical endometritis (SCE) is a postpartum uterine disease characterized by inflammation of the endometrium in the absence of clinical signs of the disease (Sheldon et al., 2006).

According to a review (Galvao, 2012), there is general agreement that SCE is highly prevalent affecting approximately 30 per cent of lactating dairy cows with a prevalence ranging from 11 per cent to 70 per cent within herd. In animals without signs of clinical endometritis, SCE is diagnosed by measuring the proportion of neutrophils present in a sample collected by a small-volume lavage of the uterine lumen or by means of a cytobrush (Gilbert et al., 2005). This uterine inflammation normally decreases with time in healthy cows. The proportion of cows with uterine inflammation diagnosed by cytology decreased from 100 per cent at 2 weeks postpartum to 89 per cent, 58 per cent, and 41 per cent at 4,6 , and 8 weeks postpartum, respectively (Gilbert et al., 2005). Subclinical endometritis is defined by the presence of more than 18 per cent PMNs in an uterine cytology sample collected between 21 and 33 days in milk (DIM) or more than 10 per cent PMNs between 34 and 47 DIM (Sheldon et al., 2006). 
Inflammation of the uterus (SCE) leads to adverse effects on reproductive performance, and also interferes with proper fertility (Gilbert, 2012). PMNs and inflammatory mediators such as cytokines, chemokines, eicosanoids, nitric oxide and oxidative stress, are characteristically associated with SCE and are shown to have negative effects on sperm, endometrium and embryos (Gilbert, 2012).

In the recent past the endometrial cytology, which is based on the migration of leucocytes to the site of infection, has been tried elsewhere to rapidly diagnose endometritis. For harvesting leucocytes from uterine secretions different methods viz. direct swab, cytobrush, aspiration and lavage have been described (Barlund et al., 2008).

Removing the inflammatory content from the uterus might be the key for improving later reproductive function and pregnancy outcome. Uterine lavage is an important therapeutic tool for treatment of uterine inflammation in equine medicine (Hurtgen, 2006 ; Liu and Troedsson, 2008).

It was proposed that it removes nonfunctional neutrophils and other inflammatory products and causes uterine contractions which aid in a physical clearance of uterine contents (Brinsko et al., 2011). Although the etiology and pathology of uterine inflammation are different in cattle compared to horses, anecdotal reports of beneficial impacts exist from practitioners who use uterine lavage to improve fertility in cows suspected to suffer from SCE.

In this present study uterine flushing techniques used to harvest the endometrial cytology in repeat breeding cows, use of low volume uterine flushing using $30 \mathrm{ml}$ sterile saline to evaluate the clearance or reduce the PMN cell in the uterine lumen to increase the conception rate in repeat breeder cows.

\section{Materials and Methods}

A total of 72 pluriparous, crossbred cows which failed to conceive after three or more consecutive artificial inseminations with good quality semen were selected during oestrus for the study. The selected cows were between $2^{\text {nd }}$ and $5^{\text {th }}$ parity. All the selected cows were randomly and equally divided into six experimental groups viz., Group I (Control group), II, III, IV, V and VI (Treatment groups). The experiment was designed with 72 cows, each group consisting of 12 cows.

\section{Endometrial cytology sample}

The cytology samples were collected from the all animal on day 0 (selection), day 4,8 and day 12. The uterine flushing was common treatment for all repeat breeder cows. The treatment protocols differ among the group after uterine flushing.

\section{Treatment}

In all the selected cows, after induction of epidural anesthesia, the uterine flushing was done just before the start of treatment day 0 (oestrus), and day 4, 8 and day 12 post oestrus. The sterile Rusch catheter (18') was inserted into the body of the uterus and the cuff was inflated with $10-12 \mathrm{ml}$ of air.

Sterile normal saline $(30 \mathrm{ml})$ solution was infused into the uterus by using a $50 \mathrm{ml}$ disposable syringe. After 3-5 min, the uterine fluid was recovered by gentle massage and back racking (Singh et al., 2000). After flushing the uterine body the catheter was removed by deflating the air. The collected flushing samples were kept in sterile tubes and stored in refrigerator for cytological examination. 


\section{Cytological examination}

All the samples were centrifuged at $1000 \mathrm{rpm}$ for $5 \mathrm{~min}$. A drop of sediment was placed on a clean slide and smear was prepared. It was fixed in methanol and stained with giemsa (Barlund et al., 2008). The leucocytic cells were counted and percentages of differential count were recorded (Schalm et al., 1975).

\section{Results and Discussion}

Repeat breeding syndrome was mainly caused due to the frequent invasion of uterus by specific and nonspecific infectious agents (Javed and Khan, 1991) which led to changes in haematological values and conception rates (Larson et al., 1980). These infections alter the uterine environment resulting in impairment of sperm transport, sperm death and hostile environment to the subsequent development and maintenance of conceptus, leading to their death, there by affecting their fertility (Azawi, 2008). The failure of uterine defense mechanisms and the presence of highly pathogenic bacteria may determine the persistence of infection and further development into endometritis (Dhaliwal et al., 2001).

In the present study the mean $( \pm$ SE) PMN cell concentration on the day of selection (0 day) was ranged between 5.60 \pm 3.82 and $12.50 \pm 2.96$ per cent. The results of the present study was concurred with the results of Gilbert et al., (2005) and Santos et al., (2009) (5 per cent), Barlund et al., (2008) (8 per cent) and Kasimanickam et al., (2004) (10 per cent) repeat breeder cows affected with subclinical endometritis. Kantharaj (2015) reported that the PMN cell concentration ranged between 5-10 per cent indicated subclinical endometritis in repeat breeder cows. The results of the present study also revealed the presence of subclinical endometritis in the repeat breeder cows
(Table 2). The mean $( \pm$ SE) PMN cells concentration on the $4^{\text {th }}$ day has increased in all the experimental and control groups and thereafter, the PMN cells were reduced marginally on day 8 and 12 . This finding was corroborated with the study of Singh et al., (2003) and Palanisamy (2012) in the endometritis affected cows.

The mean $( \pm$ SE) PMN cells concentration on the $4^{\text {th }}$ day has ranged between $7.50 \pm 2.33$ to $20.29 \pm 6.48$ per cent. This increase in the neutrophils concentration might be due to the uterine flushing carried out on the day of selection (0 day). Lavage of the uterus would have triggered the irritation of the endometrium and induced the migration of neutrophils into uterine lumen or stimulation of serum opsonins. This replacement of nonfunctional neutrophils with active neutrophils could be considered as a helpful phenomenon for killing and removing of bacteria located in the uterus (Dini et al., 2015)

The mean $( \pm$ SE) PMN cells concentration on the day 8 and 12 was ranged between $4.00 \pm 1.78$ to $11.86 \pm 6.89$ and $1.00 \pm 0.08$ to $7.00 \pm 2.92$ per cent. Inflammation of the uterus (SCE) led to adverse effects on reproductive performance, and also interferes with proper fertility (Gilbert, 2012). PMNs and inflammatory mediators such as cytokines, chemokines, eicosanoids, nitric oxide and oxidative stress, are characteristically associated with SCE and are shown to have negative effects on sperm, endometrium and embryos (Gilbert, 2012). Dini et al., (2015) also reported that the cytological study after 10 days of uterine lavage revealed the reduced PMN cell concentration in the uterus (Fig. a). Wiebold (1988) reported that most of the embryonic mortality occurred before day 5 in cows, which was associated with a uterine environment which significantly differed that of cows with normal embryos. 
Table.1 Cytological features of uterine flushing in repeat

\begin{tabular}{|c|c|c|c|c|c|c|c|}
\hline \multirow[b]{2}{*}{$\begin{array}{c}\text { Cells } \\
\text { (per cent) }\end{array}$} & \multirow[b]{2}{*}{$\begin{array}{l}\text { Uterine } \\
\text { flushing }\end{array}$} & \multicolumn{6}{|c|}{ Therapeutic Groups } \\
\hline & & Group I & Group II & Group III & Group IV & Group V & Group IV \\
\hline \multirow{4}{*}{ PMN } & $\begin{array}{c}\mathrm{I} \\
(\mathrm{D} 0)\end{array}$ & $12.50^{\mathrm{b}} \pm 2.96$ & $9.40^{\mathrm{b}} \pm 5.45$ & $5.60^{\mathrm{b}} \pm 3.82$ & $6.00^{c} \pm 2.96$ & $8.50^{\mathrm{b}} \pm 2.36$ & $9.40^{\mathrm{bc}} \pm 1.29$ \\
\hline & $\begin{array}{c}\text { II } \\
\text { (D 4) }\end{array}$ & $20.29^{c} \pm 6.48$ & $9.70^{\mathrm{b}} \pm 4.01$ & $7.50^{\mathrm{bc}} \pm 2.33$ & $11.90^{\mathrm{d}} \pm 4.09$ & $9.00^{\mathrm{b}} \pm 2.98$ & $11.60^{\mathrm{d}} \pm 3.01$ \\
\hline & $\begin{array}{c}\text { III } \\
\text { (D 8) }\end{array}$ & $11.86^{\mathrm{b}} \pm 6.89$ & $8.10^{\mathrm{a}} \pm 1.96$ & $5.20^{\mathrm{b}} \pm 2.38$ & $4.00^{\mathrm{b}} \pm 1.78$ & $8.40^{\mathrm{b}} \pm 3.68$ & $8.00^{\mathrm{b}} \pm 4.06$ \\
\hline & $\begin{array}{c}\text { IV } \\
\text { (D 12) }\end{array}$ & $4.20^{\mathrm{a}} \pm 1.89$ & $7.00^{\mathrm{a}} \pm 2.92$ & $3.00^{\mathrm{a}} \pm 1.56$ & $1.00^{\mathrm{a}} \pm 0.08$ & $1.80^{\mathrm{a}} \pm 1.21$ & $4.40^{\mathrm{a}} \pm 1.73$ \\
\hline \multirow{4}{*}{ lymphocytes } & $\begin{array}{c}\mathrm{I} \\
(\mathrm{D} 0)\end{array}$ & $16.50^{d} \pm 5.56$ & $13.60^{\mathrm{b}} \pm 4.86$ & $14.20^{\mathrm{d}} \pm 5.25$ & $12.00^{c} \pm 4.85$ & $13.60^{\mathrm{d}} \pm 5.11$ & $21.0^{c} \pm 6.13$ \\
\hline & $\begin{array}{c}\text { II } \\
\text { (D 4) }\end{array}$ & $10.20^{c} \pm 5.72$ & $3.00^{\mathrm{a}} \pm 2.58$ & $10.80^{c} \pm 5.12$ & $5.80^{\mathrm{b}} \pm 3.29$ & $9.60^{\mathrm{c}} \pm 4.52$ & $8.80^{\mathrm{b}} \pm 4.50$ \\
\hline & $\begin{array}{c}\text { III } \\
\text { (D 8) }\end{array}$ & $7.80^{\mathrm{b}} \pm 3.81$ & $3.40^{\mathrm{a}} \pm 2.02$ & $4.00^{\mathrm{b}} \pm 0.13$ & $2.20^{\mathrm{a}} \pm 1.20$ & $2.20^{\mathrm{b}} \pm 1.80$ & $6.60^{\mathrm{a}} \pm 3.29$ \\
\hline & $\begin{array}{c}\text { IV } \\
\text { (D 12) }\end{array}$ & $4.30^{\mathrm{a}} \pm 2.10$ & $3.20^{\mathrm{a}} \pm 1.02$ & $1.20^{\mathrm{a}} \pm 0.20$ & $1.20^{\mathrm{a}} \pm 0.20$ & $1.20^{\mathrm{a}} \pm 0.20$ & $5.40^{\mathrm{a}} \pm 2.50$ \\
\hline
\end{tabular}

\section{BREEDER COWS}

Mean values bearing different superscript ( $\mathrm{a}, \mathrm{b}, \mathrm{c}, \mathrm{d})$ between columns differed significantly (p<0.05). Group I - control, Group II -UF + PGF $\alpha$, Group III- UF + $\mathrm{PGF}_{2} \alpha \mathrm{GnRH}$ at the time of AI, Group IV $-\mathrm{UF}+\mathrm{PGF}_{2} \alpha \mathrm{GnRH}$ at the time of AI $+\mathrm{FM}$ on day 5 and $\left.12 \mathrm{PAI}\right), \mathrm{Group} \mathrm{V}-\mathrm{UF}+\mathrm{PGF} 2 \alpha \mathrm{GnRH}$ at the time of AI $+\mathrm{AO}$ on day 5 and $12 \mathrm{PAI}$ and Group VI - UF $+\mathrm{PGF}_{2} \alpha \mathrm{GnRH}$ at the time of $\mathrm{AI}+\mathrm{FM}+\mathrm{AO}$ on day 5 and $12 \mathrm{PAI}$. 
Fig.1(a) PMN concentration in uterine lavage; (b) Reduction in lymphocyte concentration using uterine flushing technique

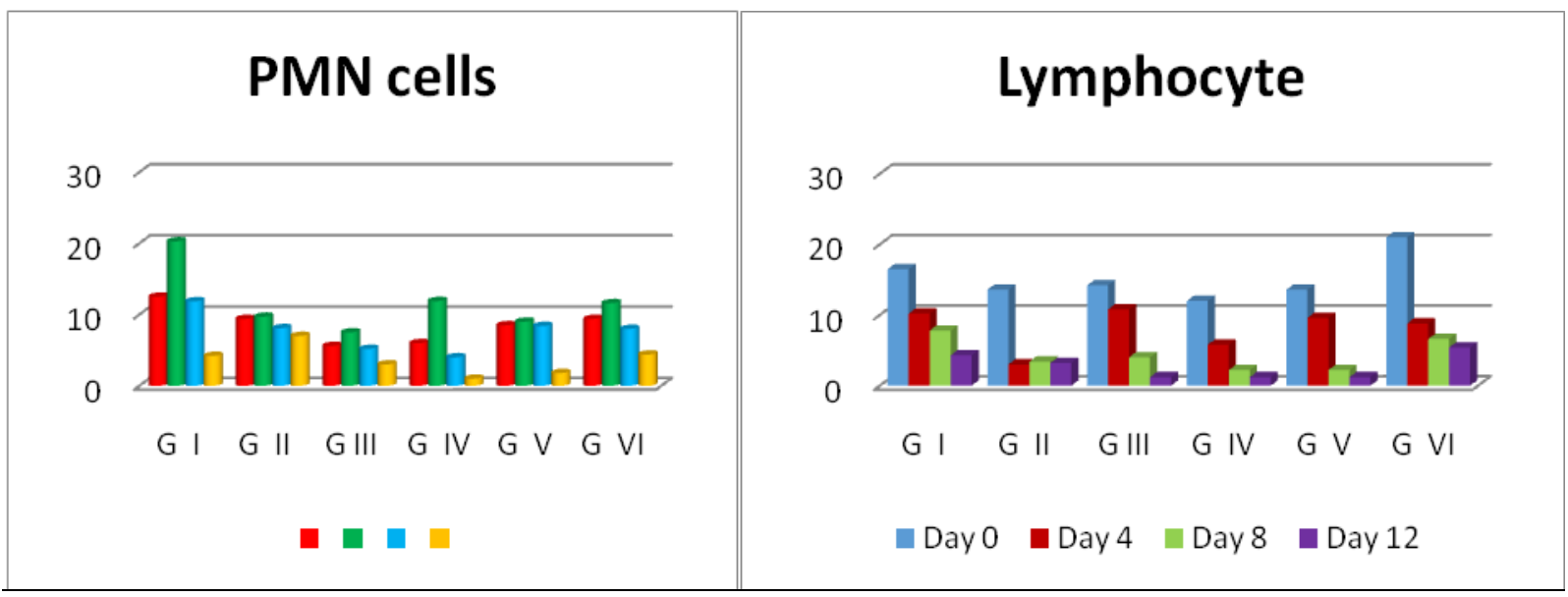

The uterine lavage exerted beneficial effect on the uterus by stimulating the uterine contraction and expulsion of debris from the uterus (Brinsko et al., 1990) and the removal of exudates from the uterine lumen and reduced bacterial population would be the reason for the reduction in the PMN cell concentration on 8 and $12^{\text {th }}$ day (Dini et al., 2015) and increased conception rate.

\section{Lymphocyte}

The mean $( \pm$ SE) lymphocyte count has registered a uniform percentage in the uterine flushing of both experimental and control cows. There was a drastic reduction in the mean $( \pm \mathrm{SE})$ lymphocyte concentration on the course of uterine flushing from day 0 (selection) to $12^{\text {th }}$ day. Uterus is supplied with ample lymphocytic drainage and contains the full range of lymphohaematopoitic cells and moleculaor regulators required to generate and elicit both humoral and cell mediated immunity. Usually lymphocytes predominate at later stages of infection and in repeaters the chronic inflammatory response would result in elevated lymphocyte concentration in uterine lumen (Babu, 2013). Wiebold (1988) reported that in chronic bacterial infection, the causative bacteria produce certain chemical factors, which inhibit the stimulation of uterine defense mechanism (UDM). The reason for low numbers of leucocytes in a natural infection could be that the prevalent bacteria were either not conductive to cause a sufficient influx of PMN or those PMN degenerated too quickly (Singh et al., 2000). The uterine flushing technique used in the study might have eliminated the uterine pathogens thereby reduction in lymphocyte concentration (Fig. b).

\section{References}

Azawi, O.I. 2008. Review, Postpartum uterine infection in cattle. Animal Reprod. Sci., 105: 187-208.

Babu, R.K., K.M. Krishna, K. Padmaja. 2013. Endocervical cytological studies in endometritis affected Murrah graded buffaloes (Bubalusbubalis). Buffalo Bull, 32: 212.

Barlund, C., T. Carruthers, C. Waldner and C. Palmer. 2008. A comparison of diagnostic techniques for postpartum endometritis in dairy cattle. Theriogenol., 69: 714-723.

Brinsko, S.P., D.D. Varner, T.L. Blanchard, S.A. Meyers. 1990. The effect of post breeding uterine lavage on pregnancy rate in mares. Theriogenol., 33: 465-475.

Brinsko, S.P., T.L. Blanchard, D.D. Varner, J. L. Schumacher, C.C. Love, K. Hinrichs and D. L. Hartman. 2011. Endometritis. In: Brinsko, S.P., Blanchard, T.L., Varner, D.D., Schumacher, J., 
Love, C.C., Hinrichs, K., Hartman, D.L. (Eds.), Manual of Equine Reproduction., 3rd edition. Mosby, Saint Louis, 73-84.

Dhaliwal, G.S., R.D. Murray, and Z. Woldehiwet. 2001. Some aspects of immunology of the bovine uterus related to treatments for endometritis. Animal Reproduction Sci., 67: 135-152.

Dini, P., M. Farhoodi, M. Hostens, M. Van Eetvelde, O. Bogado Pascottini, M.H. Fazeli and G. Opsomer. 2015. Effect of uterine lavage on neutrophil counts in postpartum dairy cows. Animal Reproduction Sci., 158: 25-30.

Galvao, K. 2012. Postpartum uterine diseases in dairy cows. Anim. Reprod. Sci., 9: 290-296.

Gilbert, R.O. 2012. The effects of endometritis on the establishment of pregnancy in cattle. Reprod. Fertil. Dev., 24: 252-257.

Gilbert, R.O., S. T. Shin, C.L. Guard, H.N. Erb and M. Frajblat, 2005. Prevalence of endometritis and its effects on reproductive performance of dairy cows. Theriogenol., 64: 1879-1888.

Hurtgen, J.P. 2006. Pathogenesis and treatment of endometritis in the mare: a review. Theriogenol., 66: 560-566.

Javed, M.T. and Khan, M.Z. 1991. Bacteriological and biohisto pathological studies in Repeat breeding cows. J. Islamic Acad. Sci., 4: 242244.

Kantharaj, S. 2015. Studies on the efficacy of Ovsynch and modified Ovsynch protocols on the conception rate in repeat breeder cows. Ph.D., Thesis submitted to the Karnataka Veterinary, Animal and Fisheries Sciences University, Bidar.

Kasimanickam, R., Duffield, T.F., Foster, R.A., Gartley, C.J., Leslie, K.E., Walton, J.S., Johnson, W.H., 2004. Endometrial cytology and ultrasonography for the detection of subclinical endometritis in postpartum dairy cows.
Theriogenol., 62: 9-23.

Larson, L.L., H.S. Mabruck and S.R. Lowry. 1980. Relationship between early post-partum blood composition and reproductive performance in dairy cattle. J. Dairy Sci., 63: 283-289.

Liu, I. and M. Troedsson, 2008. The diagnosis and treatment of endometritis in the mare: yesterday and today. Theriogenol., 70: 415-420.

Palanisamy, M. 2012. Efficacy of immunomodulators, lugols's iodine and prostaglandin $\mathrm{f}$ in the treatment of postpartum endometritis in cows. ph.D., thesis submitted to department of veterinary gynaecology and obstetrics, tanuvas, Chennai.

Santos, N.R., G.C. Lamb, D.R. Brown and R.O. Gilbert. 2009. Postpartum endometrial cytology in beef cows. Theriogenol., 71: 739-745.

Schalm, O.W., N. C. Jain and E. J. Corroll, 1975. Veterinary Haematology. $3^{\text {rd }}$ edition, Lea and Febiger, Philadelphia, USA.

Sheldon, I.M., G.S. Lewis, S., LeBlanc andR. O. Gilbert. 2006. Defining postpartum uterine disease in cattle. Theriogenol., 65: 1516-1530.

Singh, J., S. Nanda, G. S. Dhaliwal and G. R. Pangaonkar, 2003. treatement of bacterial endometritis in crossbred cows using intra uterine oyster glycogen, a non-specific immunomokulators. Indian J. Anim. Sci., 73: 844-847.

Singh, J., S.S. Sidhu, G.S. Dhaliwal, G.R. Pangaokar, A.S. Nanda and A.S. Grewal. 2000. Effectiveness of lipopolysaccharide as an intrauterine immunomodulaors in curing bacterial endometritis in repeat breeding crossbred cows. Anim. Reprod. Sci., 59: 159166.

Wiebold, J.L. 1988. Embryonic mortality and the uterine environment in first service lactating dairy cows. J. Reprod. Fertil., 84: 393-399. doi:10.1530/JRF.0.0840393.

\section{How to cite this article:}

Alagar, S., R. Ezakial Napolean, M. Selvaraju, G.A. Balasubramaniam and Selvaraj, P. 2017. Effect of Uterine Flushing on Subclinical Endometritis in Repeat Breeding Cows. Int.J.Curr.Microbiol.App.Sci. 6(7): 2493-2498. doi: https://doi.org/10.20546/ijcmas.2017.607.294 